\title{
A obra, o rosto e a mensagem: reflexões sobre a construção da área portuária de Porto Alegre [RS]
}

SELECCIÓN VIII SEMINARIO INTERNACIONAL DE INVESTIGACIÓN EN URBANISMO

\section{Larissa Lohmann}

Arquiteta e Urbanista pela Universidade do Vale do Rio dos Sinos. Mestranda pela Universidad Politécnica de Cataluña (Barcelona, Espanha). Gramado [RS] Brasil. <larissalohmann@hotmail.com>

\section{Resumo}

A investigação pretende aportar uma análise sobre o processo de construção do porto de Porto Alegre, em diálogo com a então ideologia política da capital rio-grandense. Tendo em vista os inúmeros matizes que compõe o caso de estudo, projetos e relatórios oficiais, além de testemunhos artísticos, fotografias e bibliografia sobre o tema serão estudados afim de documentar a evolução da paisagem costeira, desde seus antecedentes até a implantação do projeto "Porto Alegre porto de mar". 0 objeto deste artigo é parte integrante de uma pesquisa mais ampla que se dedica a analisar a história e os significados que envolvem o Cais Mauá. A hipótese desta tese parte da premissa de que o lugar em estudo carrega vestígios de valor tanto estético como cultural, signos da história de Porto Alegre, capazes de transmitir as etapas evolutivas da área portuária da cidade e a metamorfose da paisagem no imaginário urbano.

\section{Palavras-chave}

Porto Alegre. Área portuária. Paisagem cultural.

\section{The work, the face and the message. Reflections on the construction of the port area of Porto Alegre [RS, Brazil]}

\begin{abstract}
The research aims to contribute an analysis of the construction process of the port of Porto Alegre, in dialogue with the political ideology of the capital. Given the many nuances that make up the study case, projects and official reports, besides artistic testimonies, photographs and bibliographies on the subject will be studied in order to document the evolution of the coastal landscape, from its early stages to the implementation of the project "Porto Alegre porto de mar". The object of this article is part of a broader research dedicated to analyze the history and meanings that surround the Cais Mauá. The hypothesis of this thesis assumes that the place under study bears traces of both aesthetic and cultural value, signs of the history of Porto Alegre, capable of transmitting the evolutionary steps of the port area of the city and the landscape of transformation in the urban imaginary.
\end{abstract}

\section{Keywords}

Porto Alegre city. Waterfront area. Cultural landscape. 


\section{Introdução}

Sobre os limites costeiros do Guaíba repousam antigos armazéns de um porto - joias de um tempo em que Porto Alegre ansiava por desenvolvimento, peças de uma beleza que já se esconde por detrás de uma cultura zapping. As águas que banham a orla parecem não escutar a fugacidade que permeia a capital. 0 'Porto dos Casais' que tantas vidas sentiu e que de tantas histórias, poemas e feitos foi testemunha; o cais que deu nome à cidade e que abriu os caminhos para uma próspera economia. Sua filha Porto Alegre sofreu inúmeras sobreposições, e a paisagem da orla do Guaíba acabou em um horizonte cada dia mais silenciado. Nada obstante, a maestria da natureza segue seu espetáculo, e a cada entardecer o sol contempla as margens do lago e se une a esta paisagem repleta de significados.

O Cais Mauá, antiga área portuária da cidade de Porto Alegre, é reflexo de um tempo de ascensão, quando a cidade ainda aspirava por futuro de caráter moderno para suas terras. Do incrível esforço em favor de dinamizar a economia da região, sempre em conjunção com a nova 'estética higienista' que se propunha em tantas capitais do Brasil, surgiram um conjunto de aterros, novas edificações portuárias, e a substituição dos trapiches por um novo cais linear, moderno e inovador, como um sopro de frescor para aquelas terras.

Seus antecedentes também carregam forte identidade. 0 cenário porto-alegrense, marcado por extraordinários contrastes geográficos, ganha ainda maior destaque por seu porto lacustre, à margem norte da península central. Um conjunto de morros e planícies suaves, cobertas por uma peculiar camada vegetal, são banhadas por doces águas que ali encontraram um ponto de encontro.

A imagem única do território designa um lugar que já nasceu intencionado. Não há dúvidas quanto ao posicionamento estratégico de Porto Alegre: a Ponta do Gasômetro oferece um excelente refúgio dos ventos sul, protegido por recortes, pontas e enseadas que o separa do mar aberto. A poderosa posição atuou como porto natural e formou ancoradouro seguro para quem vinha de mares longínquos e pretendia incursionar continente adentro.

Até finais do século XIX, em torno da baía aglomeravam-se comerciantes e quitandeiros, acocorados junto às suas mercadorias. A imagem era de um sem-fim de trapiches dispostos sobre o rio. Também foi ponto de início, repleto de sonhos e esperanças dos imigrantes recém-chegados. Um interessante relato de Auguste de Saint-Hilaire (1820), em ocasião de visita à cidade, descreve em detalhes a imagem do antigo cais de Porto Alegre:

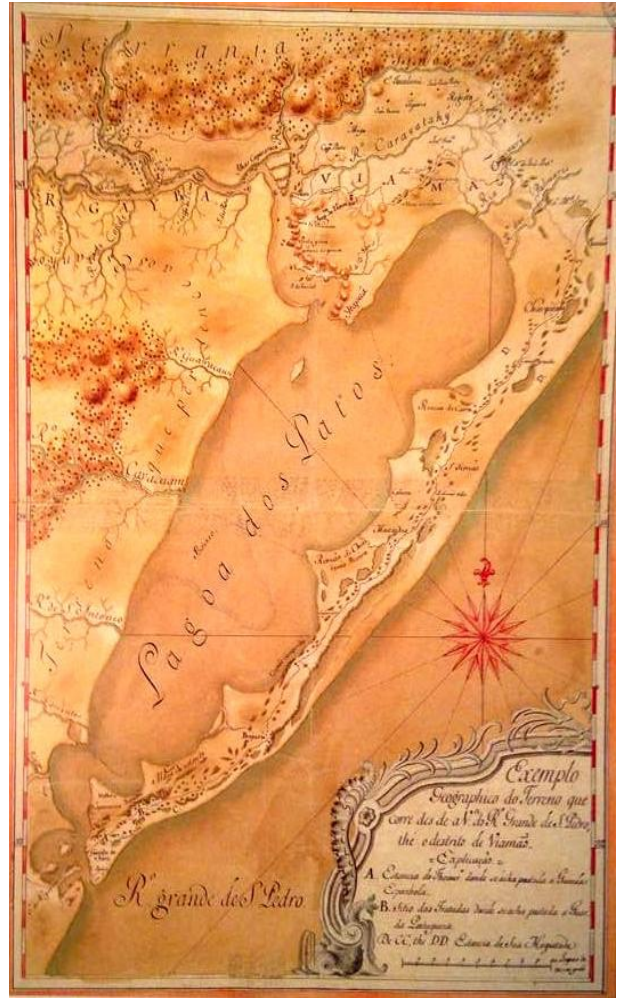

Figura 1. Mapa da região costeira do Rio Grande do Sul, elaborado por José Custódio de Sá e Faria, 1763. Fonte: Atlas Ambiental de Porto Alegre.

[...] um grande cais que avança para a lagoa, e à qual se tem acesso por uma larga ponte de madeira de aproximadamente cem passos de comprimento, guarnecida de peitoris e sustentada por pilares de pedra. As mercadorias, que aí se descarregam, são recebidas na extremidade dessa ponte, debaixo de um armazém de vinte e três passos de largura por trinta de comprimento, sustentado sobre oito pilastras de pedra, em que se apoiam outras de madeira. A vista desse cais seria de um belo efeito para a cidade, se não fosse prejudicada pela construção, à entrada da ponte, de um edifício muito pesado e rústico que mede quarenta passos de comprimento, para servir de alfândega (Saint-Hilaire, 1820).

\subsection{As peças do retrato}

Os treze armazéns dispostos linearmente, juntamente com o Pórtico Central (considerado 
patrimônio cultural nacional desde 1983), formam um conjunto que foi construído por etapas. Em 1911 começaram as obras do Cais Mauá, e somente após 38 anos, o porto tem seu projeto completo executado.

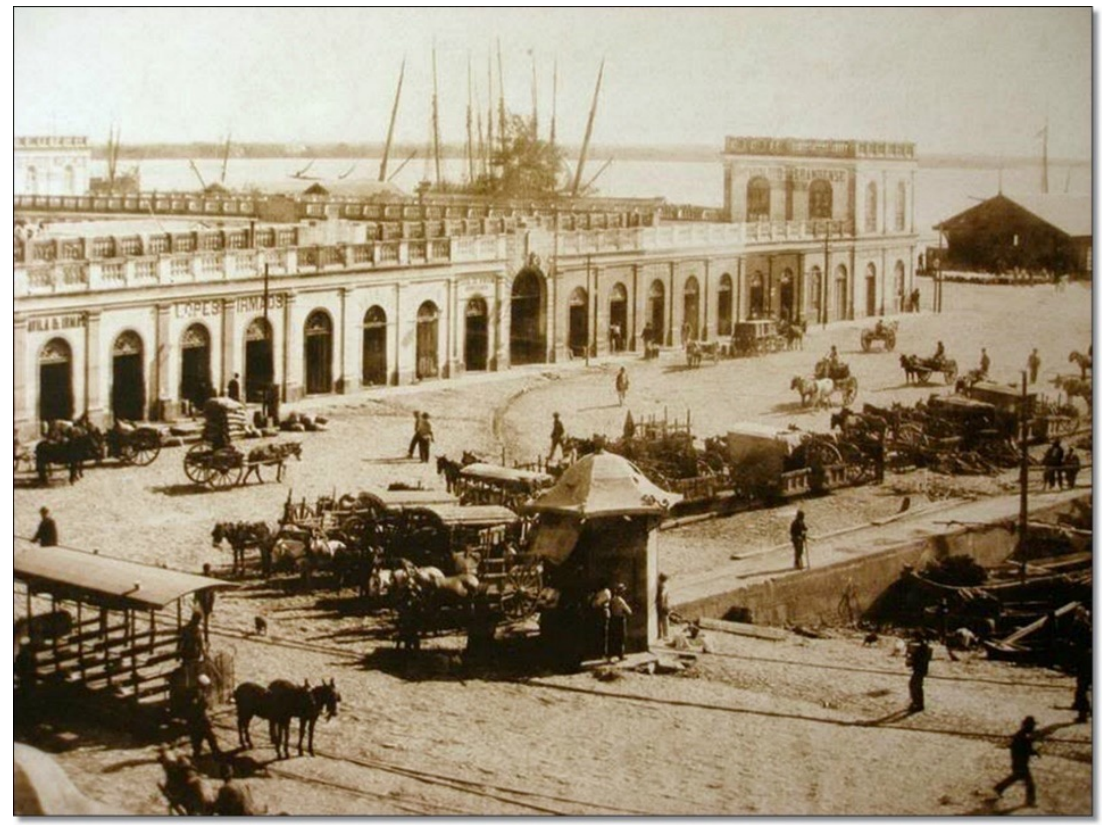

Figura 2. Mercado Público e a doca das frutas, 1895.

Fonte: http://antigaportoalegre.no.comunidades.net/fotos-1800-1900.

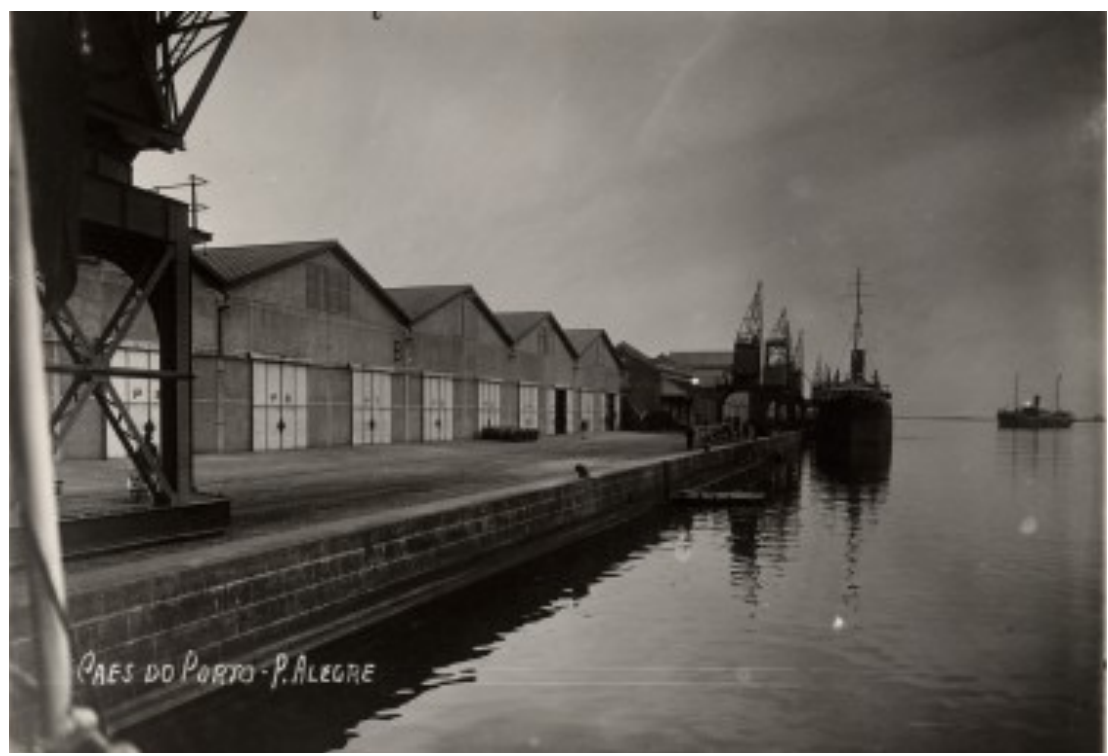

Figura 3. A imagem dos primeiros anos de operação do novo porto, na década de 1920. Fonte: Acervo do Museu Joaquim José Felizardo/Fototeca Sioma Breitman.

O Pórtico Central do Cais merece destaque por sua estrutura e pelo esforço empreendido para sua execução. No entanto, esta peça singular do Cais Mauá tem antes de tudo um sentido tão poético que perpassa seu valor construtivo. Representava a 'porta da cidade', fato no qual o célebre escritor Érico Verissimo comentava: Porto Alegre era uma das poucas cidades, ou talvez a única onde os visitantes entravam direto no centro da cidade. As antigas gruas para movimentação de cargas, dispostas em trilhos metálicos, também estão protegidas patrimonialmente como parte integrada ao conjunto arquitetônico.

Além da conjunto de construções do Cais Mauá, merece ressalva um hiato próximo da área: a Usina do Gasômetro, uma antiga usina geradora de energia que hoje é palco das mais diversas manifestações artísticas. 0 complexo arquitetônico da usina é composto por um edifício de 
características únicas (datado de 1928) e uma majestosa chaminé de 117 metros construída anos depois da inauguração da usina. Um marco na paisagem; outro vestígio da evolução econômica e industrial de Porto Alegre. A usina foi desativada em 1970, e por incentivo de inúmeras manifestações, o complexo foi reformado, tombado e transformado em um centro cultural. Neste bonito exemplo onde a arquitetura se une a paisagem, é onde se celebra uma das maiores tradições de Porto Alegre: ver o espetacular pôr-do-sol da cidade, às margens do Guaíba, de preferência acompanhado de um bom mate amargo.

\subsection{Anatomia da investigação}

Porque preservar, em que consiste a identidade do Cais Mauá, quais vestígios devem ser valorizados na revitalização e quais são as oportunidades que este lugar carrega. Este conjunto de inquietações impulsionaram esta investigação, sempre acompanhadas da intuição de que o Cais Mauá traz consigo um material singular e uma rica oportunidade para a cidade capital do Rio Grande do Sul.

Entende-se que as heranças históricas são como pontos fortes costurados no tecido urbano. Mesmo que a paisagem habite em pausa, o bordado trabalhado pelo homem não se desfaz. Na memória dos antigos ou no jovem olhar da atualidade, o lugar tece uma complexa e bonita rede de relações carregada de símbolos dignos de serem preservados, revelados e celebrados.

Parte integrante de uma pesquisa mais ampla, o presente artigo propõe analisar o processo de construção da área portuária de Porto Alegre e relacionar os projetos e a obra com o ideário político então vigente. Documentos oficiais correspondentes ao período da República Velha (1895-1930) serão estudados afim de chegar a uma compreensão mais detalhada sobre a mensagem que esta notável obra manifestou. Ao descortinar a imagem do 'Porto dos Casais', signo de uma época de pujança econômica, se propõe entender o legado e os significados deste lugar de presença forte no imaginário urbano porto-alegrense.

Uma cidade que nasceu como porto, cresceu como porto, e se desenvolveu graças a sua atividade portuária. 0 espírito da paisagem, de rara e impressionante composição, acompanhou a evolução da cidade desde sua fundação. 0 texto traz o retrato e as transformações desta península que fez nascer Porto Alegre, o valor da geografia que alentou os açorianos (primeiros personagens deste enredo) e a imagem ondulante da cidade primitiva, terra de embarque e desembarque, abrigo de todas as gentes.

A hipótese central desta investigação parte da premissa de que a construção do porto de Porto Alegre foi resultado de uma série de esforços. Sem a audácia da política positivista e dos personagens envolvidos, o sonho da reconfiguração da costa portuária, e a subsequente modernização da capital, ficaria apenas como um projeto esquecido. Sob este enfoque, intui-se que a paisagem costeira portuária de Porto Alegre, além de apresentar traços naturais únicos e de vital importância para a fundação da cidade, carrega também vestígios de valor tanto material quanto imaterial sobre a história de Porto Alegre.

\section{Notas sobre Porto Alegre}

Quem é essa tal cidade Porto Alegre? Quais são suas virtudes e que gente vive lá? Ora com doçuras femininas de uma "rapariga caprichosa", por sua primavera amena e suas águas tranquilas. Ora com asperezas de homem, pelo frio e cinzento inverno que chega sem avisar.

Laborioso desafio interpretar o porto que se viu alegre desde seus primórdios tempos. Porto Alegre, sede capital do Rio Grande do Sul, repousa sobre uma península formada por colinas e banhada pelo Guaíba, numa espécie de promontório.

Há de se advertir que, enquanto Salvador da Bahia e São Sebastião do Rio de Janeiro já eram cidades quase bicentenárias, as terras do Guaíba ainda pertenciam ás an(danças) de índios. Onde hoje despontam os arranha-céus da península, em princípios do século XVIII o que dominava a paisagem eram ocas de palha da tribo tape-minuano. 
A região foi elevada à categoria de Vila em princípios do século XIX, quando um pequeno povoado açoriano já instituía as bases da futura capital; e deste tempo não tardou em transformar-se principal entreposto da capitania.

Verissimo a definia como "meio termo", a cidade mais classe média do país. Ousava dizer que o visitante não encontraria elementos suficientemente predominantes para determinar as influências arquitetônicas da cidade:

Ali está uma casa com algo de rococó, mais adiante outra com vestígios de barroco, ao pé de uma terceira cuja fisionomia é irremediavelmente colonial (Verissimo, 1954, p.8).
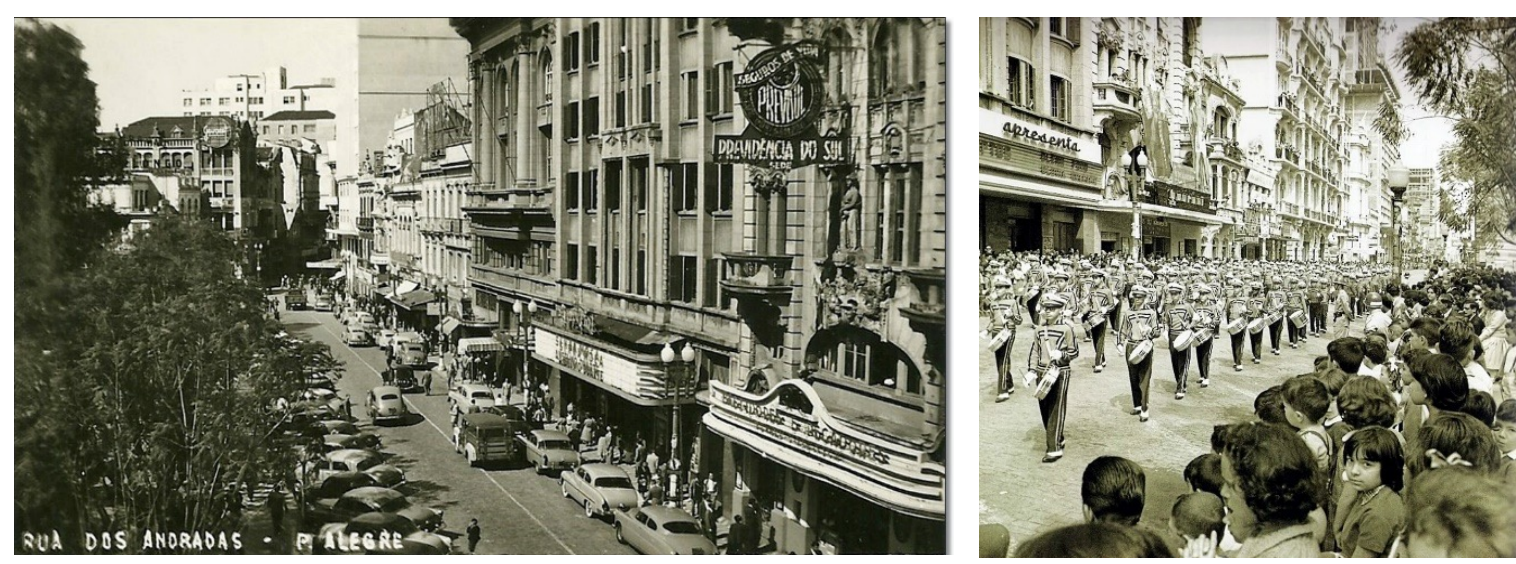

Figuras 4 e 5. Rua das Andradas em dois tempos: 1956 e em 1960, em ocasião de Desfile de 20 de setembro. Fonte: http://antigaportoalegre.no.comunidades.net/fotos-1941-1960

Deveras, a multiplicidade representa a alma da cidade. 0 açoriano teve o dom quase ilusionista ao recriar sua paisagem lusitana à beira do Guaíba, mesmo sem as cantadas promessas do Rei. 0 estrangeiro alemão e italiano fez a capital amadurecer, pois trouxe junto consigo seus milênios e suas lendas. Porto Alegre é certamente um rico mostruário multifacetado, algo como um caleidosópio cultural.

\subsection{As regras do território}

As características litorâneas da capital, principalmente nos limites sul e sudoeste, se deve ás águas do Lago Guaíba, que numa espécie de sequência natural, misturam-se ás águas da Laguna dos Patos, que por fim abre passagem para o Oceano Atlântico Sul. Uma bonita dança de águas, embalada por elemento dominante da área: os ventos Sul.

Guayba, como era denominado o território nos prelúdios de sua ocupação, significa "encontro de rios" na linguagem tupi-guarani. De fato, as águas de quatro rios afluem e convergem nesta região, formando um delta - embocadura onde ser água é ser eternamente percurso. Ali se encontram o Rio Jacuí, o Rio Caí, o Rio dos Sinos e o Rio Gravataí. Quando esses rios desembocam no lago, formam o chamado Delta do Jacuí. Foi neste encontro que muitos casais açorianos inventaram vida nova.

Com forma de cotovelo, o Lago Guaíba tem cerca de 50 quilômetros de comprimento, $470 \mathrm{~km}^{2}$ de superfície, e estende-se desde o Delta do Jacuí, ao Norte, até a Ponta do Itapuí, ao Sul, onde apresenta a profundidade máxima de 31 metros. 0 regime de escoamento das águas é bidimensional, e fortemente controlado pelas flutuações do nível d'água da Laguna dos Patos e pela direção e intensidade dos ventos predominantes na região. $\mathrm{Na}$ área da Ponta do Gasômetro, próxima ao centro de Porto Alegre, o fluxo da água pode variar, num mesmo dia, tanto no sentido Sul como no Norte, resultando o represamento das águas e ocasionalmente as temidas inundações na cidade.

A topografia da cidade impacta por seus contrastes, fato que se deve ao encontro de todos os domínios morfoestruturais do Rio Grande do Sul. O conjunto de cristas, colinas, planícies, enseadas e pontas são os protagonistas deste cenário. Um conjunto mesclado, e, como uma obra de Kandinsky, cada peça desenvolve seu papel, sua razão de ser. 
Dos conjuntos de elevações presentes no território, a Crista da Matriz representa uma das peças mais importantes por nascer na península que cedeu espaço à nova urbanização que surgia com a chegada dos açorianos. A Crista da Matriz nasce na Ponta do Gasômetro, e, em direção leste-oeste, prolonga-se pela atual Avenida Independência e prossegue pelos morros Petrópolis e Alto Petrópolis. Com um olhar sensível, nota-se que o percurso tanto da Crista da Matriz, quanto dos outros conjuntos topográficos, correspondem ao traçado atual de Porto Alegre. Como um espelho, a imagem compositiva e principalmente viária da cidade reflete a complexa topografia de Porto Alegre.

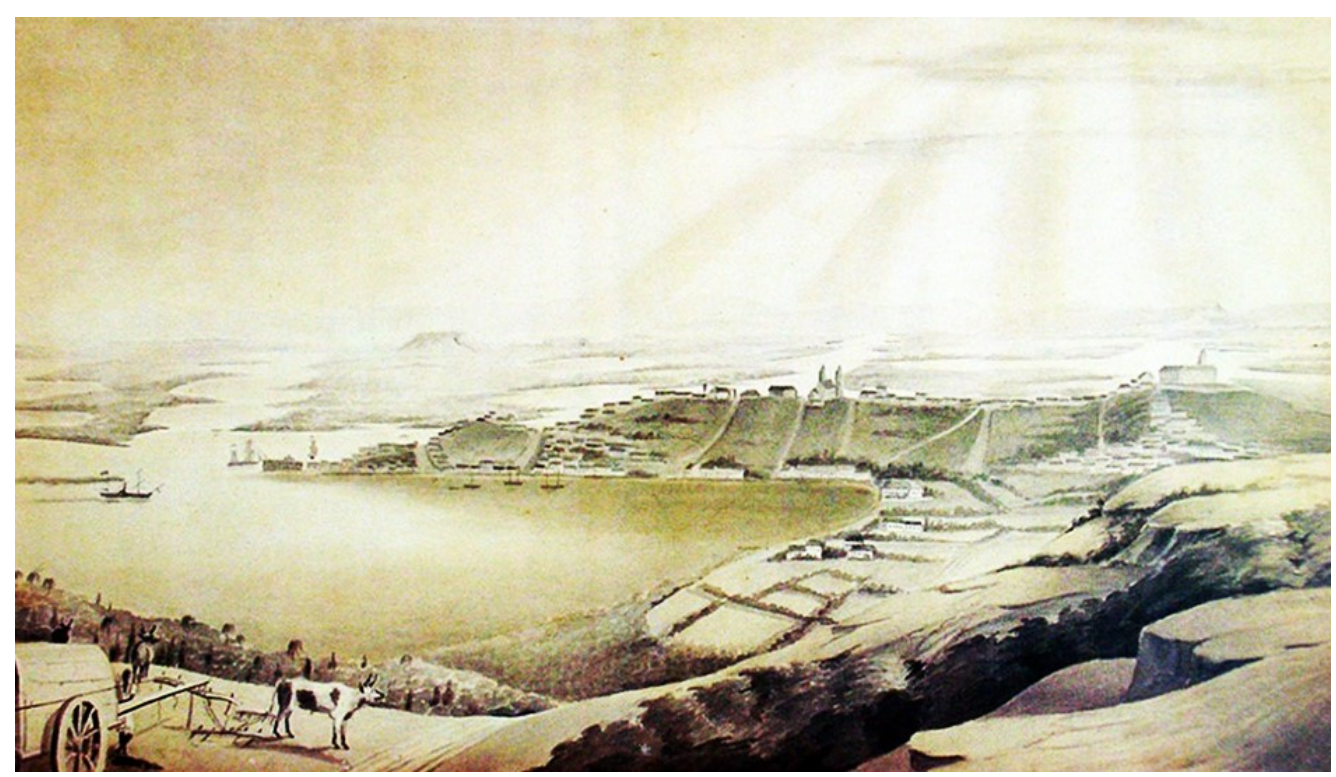

Figura 6. Porto Alegre, vista da zona sul, 1852.

Fonte: http://antigaportoalegre.no.comunidades.net/fotos-1800-1900.

O solo gaúcho não foi somente espectador da história da cidade - se fez presente em sua eternidade metafísica, com seus próprios códigos, e tornou possível a manifestação de uma cultura múltipla, "forte, aguerrida e brava", nas palavras do hino rio-grandense. 0 que definiu a trama costurada neste tapete verde prometido foi a topografia singular deste território. A planície do Arroio Dilúvio constituiu eixo de ligação, os cumes das colinas foram conectados por caminhos, as águas do Guaíba garantiram a construção e o desenvolvimento desta cidade. A península, batizada como Ponta do Gasômetro, trouxe louros por sua posição incrivelmente estratégica - foi como um convite, honroso, para aqueles que tiveram a coragem de 'aprochegar-se' em terras desconhecidas.

\subsection{Alicerces urbanos}

Porto Alegre não foi presenteado com um plano inicial de colonização. Para os portugueses, não era tão importante definir um plano, diferentemente da ideologia praticada nas colonizações espanholas no território americano. 0 objetivo da colonização de Porto Alegre era primeiramente manter o domínio da costa e proteger as divisas recém conquistadas.

O Tratado de Tordesilhas, de 1494, perdia forças desde o início do século XVII para a perspicácia dos bandeirantes e tropeiros, que adentravam as terras contrárias em busca de escravos índios e rebanhos de gado bovino, mulas e cavalos que viviam livres no estado. Naqueles tempos, as terras próximas ao Guaíba foram dominadas por estancieiros, resultando num conjunto de sesmarias.

Após assinado o Tratado de Madrid, em 1750, o rei de Portugal determina a reunião de casais da Ilha dos Açores afim de povoar as terras do Sul recém conquistadas. Após a chegada dos colonizadores açorianos, o então Porto de Viamão é elevado a freguesia e nomeado Freguesia de São Francisco do Porto dos Casais, em 26 de março de 1772 (data oficial reconhecida como fundação da cidade).

A joia literária $O$ Tempo e o Vento, do ilustre gaúcho Erico Verissimo (1949), dedica um trecho aos personagens deste tempo de incertezas e desafios em terras virgens. Com suas palavras de ficção, a obra carrega a alma desta história: 
[...] Zé Borges na praça de Angra soletra o edital d'El -Rei.

[...] fazer mercê aos Casais das ditas Ilhas, que se quiserem estabelecer no Brasil de lhes facilitar o transporte e estabelecimento, mandando-os transportar à custa de sua Real Fazenda, não só por mar, mas também por terra até os sítios que se lhes destinarem para as suas habitações, não sendo homens de mais de quarenta anos e não sendo as mulheres mais de trinta [...]

\section{[...] Crescem os olhos de Zé Borges, ao lerem as promessas d'El-Rei.}

[...] e logo que chegarem aos sítios que hão de habitar se dará a cada casal uma espingarda, duas enxadas, um machado, uma enxó, um martelo, um facão, duas facas, duas tesouras, duas verrumas e uma serra com sua lima e travadoura, dois alqueires, duas vacas e uma égua [...] (Verissimo, 1949).

Assim como Zé Borges e sua mulher na ficção, outros tantos casais da Ilha dos Açores em Portugal devaneiam com as promessas do outro lado do oceano, onde o dia é mais jovem, assim como a vida que os esperava por lá. 0 açoriano põe-se a sonhar sobre suas vinhas; vê suas terras e rebanhos, come o pão de seu trigal e vê seus filhos já crescidos. Assim caminham em direção ao porto, carregando lágrimas e trouxas, num misto de saudade e esperança.

Por esses tempos, muitos desciam ao Sul em busca de terras e gado - que pertenceriam a quem os encontrassem primeiro. Muitos navegavam em busca de ouro e prata. Assim como o trigo do açoriano, que crescia e amadurecia, novos povoados surgiam nos vales e nas margens daqueles rios.

Primeiramente, as casais açorianos foram encaminhados a terras no Morro Santana, mas o local era pobre em fontes de água. Assim, a população decidiu se instalar próximo ao porto natural. Por conseguinte, um tímido povoado começa a nascer próximo ao porto natural que recebera os novos habitantes. De 1772 a 1820, a produção de trigo movia a economia de Porto Alegre, além de sua função portuária principalmente para apoio à produção. Neste período, foram construídos a primeira sede de governo, um cemitério, uma prisão, um pequeno teatro e a Igreja Matriz. Pouco a pouco, o comércio começa a florescer, e a atividade portuária se intensifica por consequência do desenvolvimento da urbe.

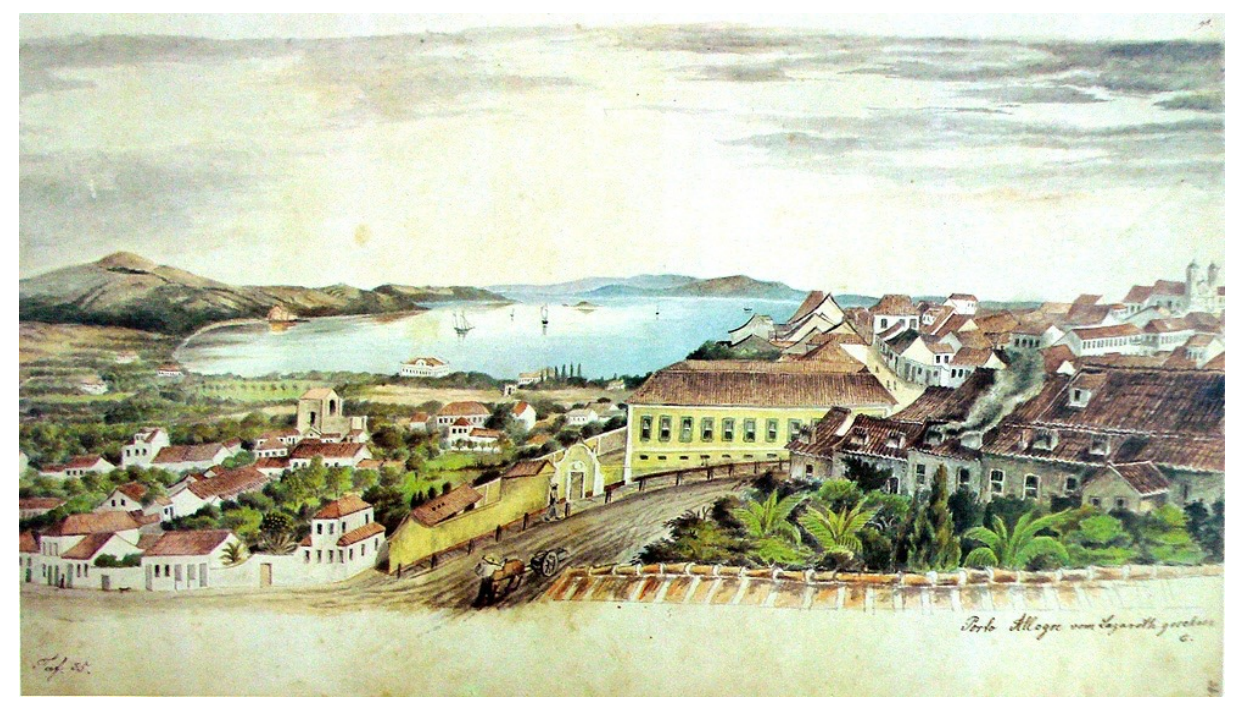

Figura 7. Porto Alegre, 1852. Obra de Herrmann Wendroth.

Fonte: http://profciriosimon.blogspot.com.es/2012_05_01_archive.html

Em análise sobre o primeiro pequeno núcleo urbano que se formou em Porto Alegre, alguns aspectos revelam-se mais evidentes. Da aparente dissociação do conjunto e a consequente fratura do sistema ortogonal, nascem elementos urbanos de natureza excepcional, vinculados às elevações topográficas e às circunstâncias locais do relevo. Destas 'quebras' da matriz regular, surgem espaços urbanos que funcionam como articuladores. É o caso do Alto da Praia, cujo desenho irregular e excepcional constitui ligação essencial entre as diferentes partes do traçado. 
A designação toponímica da planta de Porto Alegre de 1772 apresenta forte referência à origem daquele povoado. Alto, Largo, Cais; nomenclatura lusitana que os açorianos trouxeram junto ás suas trouxas e baús ao 'Novo Mundo'. Vocabulário este que não deriva de uma legislação ou regra oficia, mas que age de forma empírica, passada de geração a geração com a sensibilidade cultural adquirida com a prática ao longo do tempo.

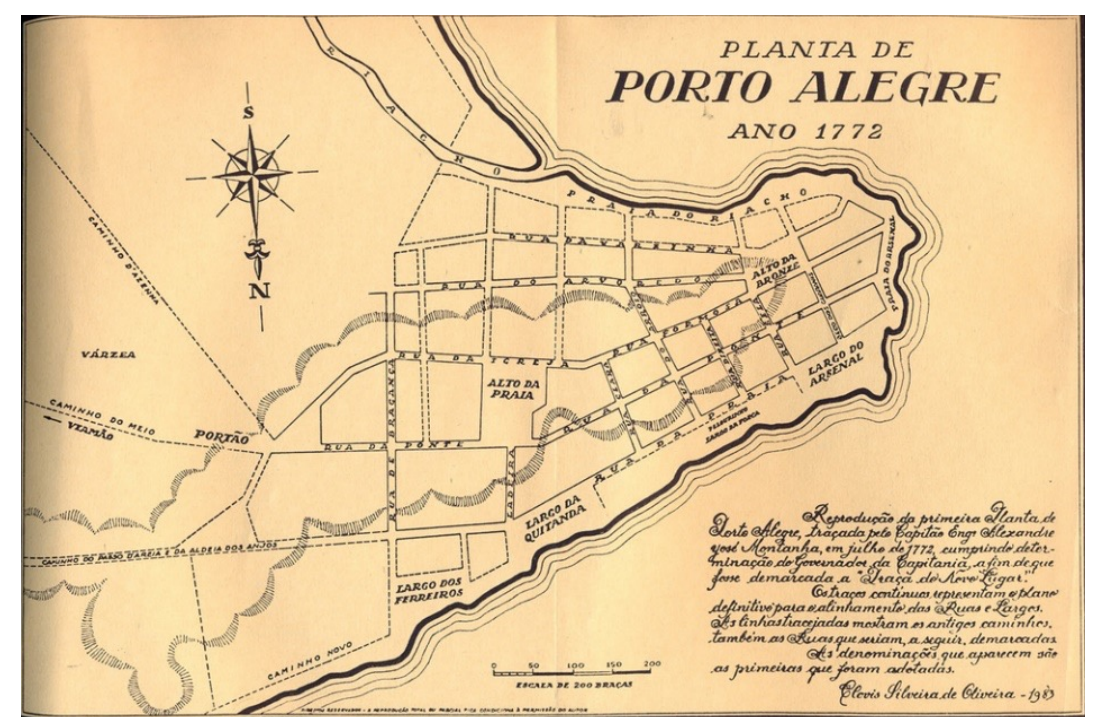

Figura 8. Planta de Porto Alegre, 1772. Fonte: http://antigaportoalegre.no.comunidades.net/seculo-xix

Alguns nomes se referem a posição topográfica do elemento urbano. O Alto, por exemplo, sugere o que tem maior altura que a ordinária; designa localização numa posição topográfica elevada e dominante da envolvente. Por outro lado, a designação caminho refere-se a função urbana do elemento, e designa genericamente todas as faixas de terreno que conduzem de um lugar a outro. É sinônimo vereda, via, espaço que se percorre. É o caso do Caminho do Meio, que conectava Porto Alegre ás terras de Viamão. A imagem de Porto Alegre no século XIX também estampa as referências lusitanas. A Rua da Praia, uma das vias mais importantes na capital por ser até hoje o principal eixo comercial, tinha cara bastante marcada por elementos arquitetônicos e de tratamento próprios de Portugal. Desde ás janelas de guilhotina ás calçadas desenhadas com mosaicos de pedra, a imagem da cidade remete ás origens do povoado.

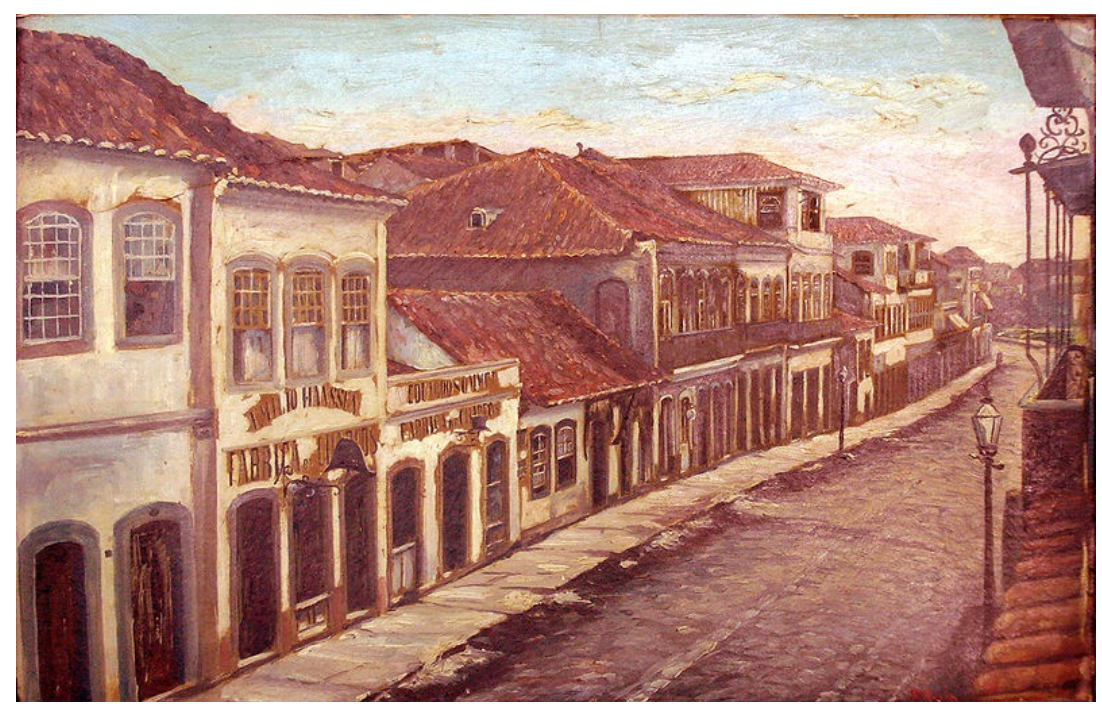

Figura 9. Rua da Praia, 1890. Artista anônimo. Fonte: Acervo Museu Júlio de Castilhos.

\subsection{0 sistema construído}

No início do século XIX, a freguesia foi elevada à categoria de Vila. Em dezembro de 1812, Porto Alegre torna-se sede da Capitania de São Pedro do Rio Grande do Sul. Com posição geográfica 
favorável, na confluência das duas maiores rotas de navegação interna da época, a capital avança como maior centro comercial da região.

Em passagem por Porto Alegre, em 1820, o biólogo francês Auguste de Saint-Hilaire retrata em seu diário traços de uma cidade em ascensão. Suas palavras expõem a imagem, a cultura, os costumes. 0 rosto da cidade, quase que milimetricamente observado e de maneira muito autêntica, é detalhado desde ás suas características físicas e geográficas, até a beleza das mulheres portoalegrenses, "muito claras, coradas e várias delas muito bonitas".

O visitante aponta a 'aprazível posição' de Porto Alegre, situada sobre uma península formada por uma colina sobre a Lagoa dos Patos. Desenha com poesia a imagem do território, as águas sensíveis do Guaíba e o labirinto das Ilhas. Também revela as características urbanas daqueles tempos: a cidade era composta por três ruas principais, que estende-se por todo comprimento da península, paralelamente à lagoa, sendo atravessadas por outras ruas transversais, mais curtas e traçadas sobre o declive da colina.

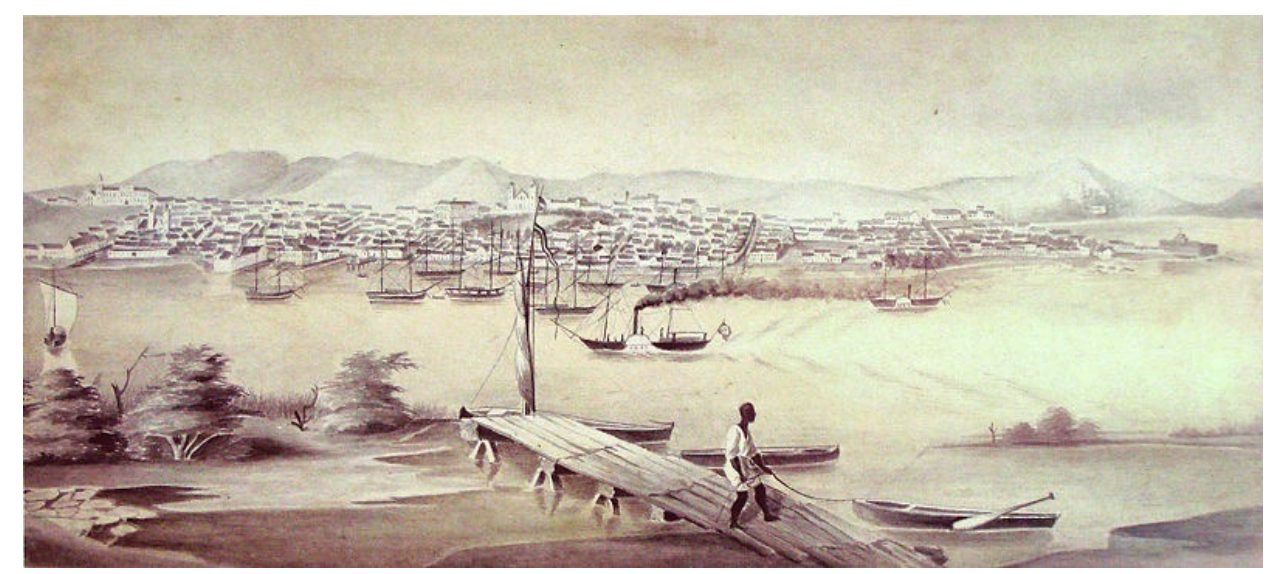

Figura 10. Imagem de Porto Alegre, vista das Ilhas, 1852.

Fonte: http://antigaportoalegre.no.comunidades.net/fotos-1800-1900

"Alguma coisa de calmo que convida ao sonho"; assim que Saint-Hilaire descreve o panorama diante de seus olhos. No cume da colina, na chamada Rua da Igreja (atual Rua Duque de Caxias), o biólogo entende que as peças arquitetônicas não condizem com a beleza do horizonte, nem correspondem à importância da cidade e riqueza da Capitania. Do alto da Crista da Matriz, onde situam-se o Palácio, a Igreja Paroquial e o Palácio da Justiça, avista-se a lagoa serpenteada por braços de quatro rios que ali deságuam. E para completar a sublime paisagem que percorria os olhos do estrangeiro, no horizonte avistava os cumes da Serra Geral, "que toma a direção de leste para norte e se perde à distância".

Seu relato aponta as más condições das moradias, esparsas e mal alinhadas, na maior parte pequenas e mal construídas. As casas são cobertas de telhas pintadas de branco em sua parte anterior e construídas em tijolo sobre alicerces de pedra. Além disso, a movimentação do porto impressiona o visitante:

Desde que aqui me encontro, já contei cerca de vinte a vinte e cinco embarcações no porto, e asseguram-me que há, muitas vezes, até cinquenta. Podem entrar no porto sumacas, brigues e embarcações de três mastros (Saint-Hilaire, 1820).

No entanto, ao final do relato, Auguste de Saint-Hilaire releva confiança no futuro da cidade, ao escrever que Porto Alegre deveria, em breve, tornar-se rica e florescente, principalmente devido ao aumento populacional da região. Naqueles tempos, era considerada como principal entreposto da Capitania, onde os negociantes recebiam mercadorias do Rio de Janeiro, as distribuindo para os arredores da região, e em troca exportavam couros, trigo e carne seca.

A intuição de Saint-Hilaire se fez valer. A imigração alemã e posteriormente a imigração italiana no Rio Grande do Sul atua como catalisador econômico da região. A proximidade dos rios nas 
zonas coloniais propicia a agricultura de policultura, em que o excedente produzido era destinado para venda ou troca. Esta permuta comercial entre Porto Alegre e a colônia determinou o futuro da capital do Rio Grande do Sul.

Com sabor de epopeia de uma colonização, a formação de um mercado interno e a nova dinâmica comercial brinda maior poder aquisitivo à uma parcela considerável da população. Assim, o imigrante passa de 'elemento de povoamento' para peça fundamental na dinamização econômica com a policultura e o artesanato/manufatura, atingindo, no final do século XIX, posição de elite financeira estadual.

A partir deste ponto, a cidade irá sofrer outros câmbios relativos à sua imagem. A cultura europeia irá invadir as novas construções e aspectos urbanos de Porto Alegre, principalmente pela influência dos imigrantes alemães já consolidados na capital. Porto Alegre irá ganhar diversas construções ao sabor europeu, como o Teatro São Pedro, um projeto tão esperado pela população e projetado em estilo neoclássico pelo arquiteto Filipe Normann. Em pouco tempo, a capital perde seus ares coloniais predominantes para mesclar-se com uma máscara classicista imposta por aqueles que então triunfavam nas terras gaúchas.

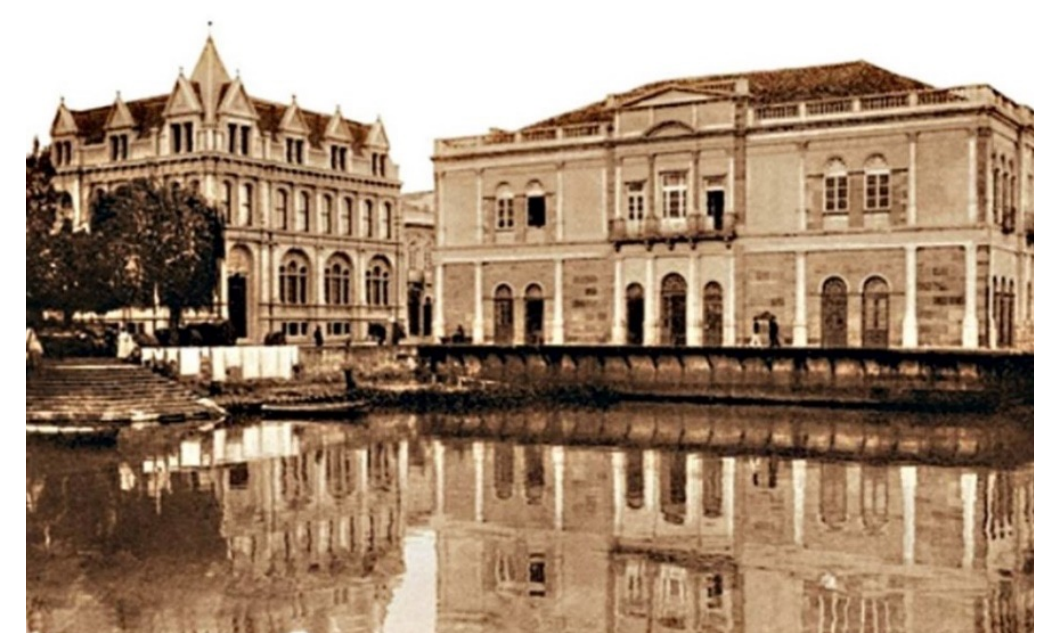

Figura 11. O Cais em 1909.

Fonte: http://antigaportoalegre.no.comunidades.net/fotos-1901-1920

Enquanto que a natureza ditou suas regras, o povoado que surgia estampou sua saudade por meio da imagem. Por meio de calçadas, caixilhos, feições e costumes, o lusitano sentia mais de perto suas terras de origem; avistava além do mar o que deixara para trás. 0 alemão melindrou sua arquitetura; trouxe o teatro, a literatura e a música à tona para reviver suas origens europeias, que virou apenas lembrança por almejar vida mais próspera.

\section{A construção de um símbolo}

"Para quem é alegre, ser bela é consequência". As palavras de Luiz Antônio de Assis Brasil elucidam a cidade capital mais ao sul do Brasil. Em prelúdios do século XX, em um até então pequeno núcleo colonial a beira do Guaíba, surge uma metrópole com aspirações modernas, numa certa ânsia por grandeza, por um desejo de se afirmar como capital do território gaúcho. Em termos demográficos, Porto Alegre somente iria ultrapassar a linha dos cem mil habitantes no fim da década de 1910 . Todavia, a população crescia a taxas anuais médias de 5,9\% - dado compatível com a fase em que a indústria porto-alegrense atinge hegemonia no estado.

A relação entre a cidade capital mais sul do Brasil e seu ancoradouro foi tema constante no planejamento da cidade e teve inúmeras alternativas propostas. A construção de um novo porto, além de marcar o período de reformas urbanas de Porto Alegre, configurava um ato simbólico: a experiência estava estritamente ligada a modernização da cidade. Esta última que ansiava em 
trocar seus trajes coloniais por uma imagem mais condizente com os novos tempos que se aproximavam.

O plano para um novo cais figurou cedo nas intenções do vereadores de Porto Alegre. Prova deste fato se encontra em proposição encaminhada ao presidente da Província em meados de 1833:

Artigo Primeiro - Que da Ponta do Arsenal se tire uma linha reta ao Caminho Novo, e que, reservando os lugares necessários para estaleiros de construção, se distribuam todos os terrenos à margem pelas pessoas que quiserem e estiverem nas circunstâncias de os aterrar, $e$ construir o cais de sua testada no prazo infalível de um ano, debaixo de pena de comisso, devendo ficar uma rua de 80 ou mais palmos entre o cais e os edifícios (Franco, 1988, p. 322).

Independente ou não de uma certa ingenuidade na mensagem do vereador, que propunha que toda a extensão a do cais seria construída a custa dos proprietários vizinhos, a proposta para renovar a área costeira da capital não foi levada a diante. Não obstante, o desejo de afeiçoar as margens do Rio Guaíba à sua cidade não cessou durante todo o século XIX.

\subsection{Prelúdio}

O primeiro projeto elaborado para o Cais, ao final do século XIX, centrava-se quase que exclusivamente em solucionar os problemas de insalubridade das margens do Guaíba. Melhorar as condições de vida do litoral da península era assunto primordial nas discussões. No entanto, como utopia criada pelo imaginário sanitarista da época, a transformação espacial do porto foi acompanhada de uma série de regulamentações e códigos de posturas municipais, com o objetivo de alterar não somente a estética do Cais, mais também de estabelecer mudanças nos hábitos da população.

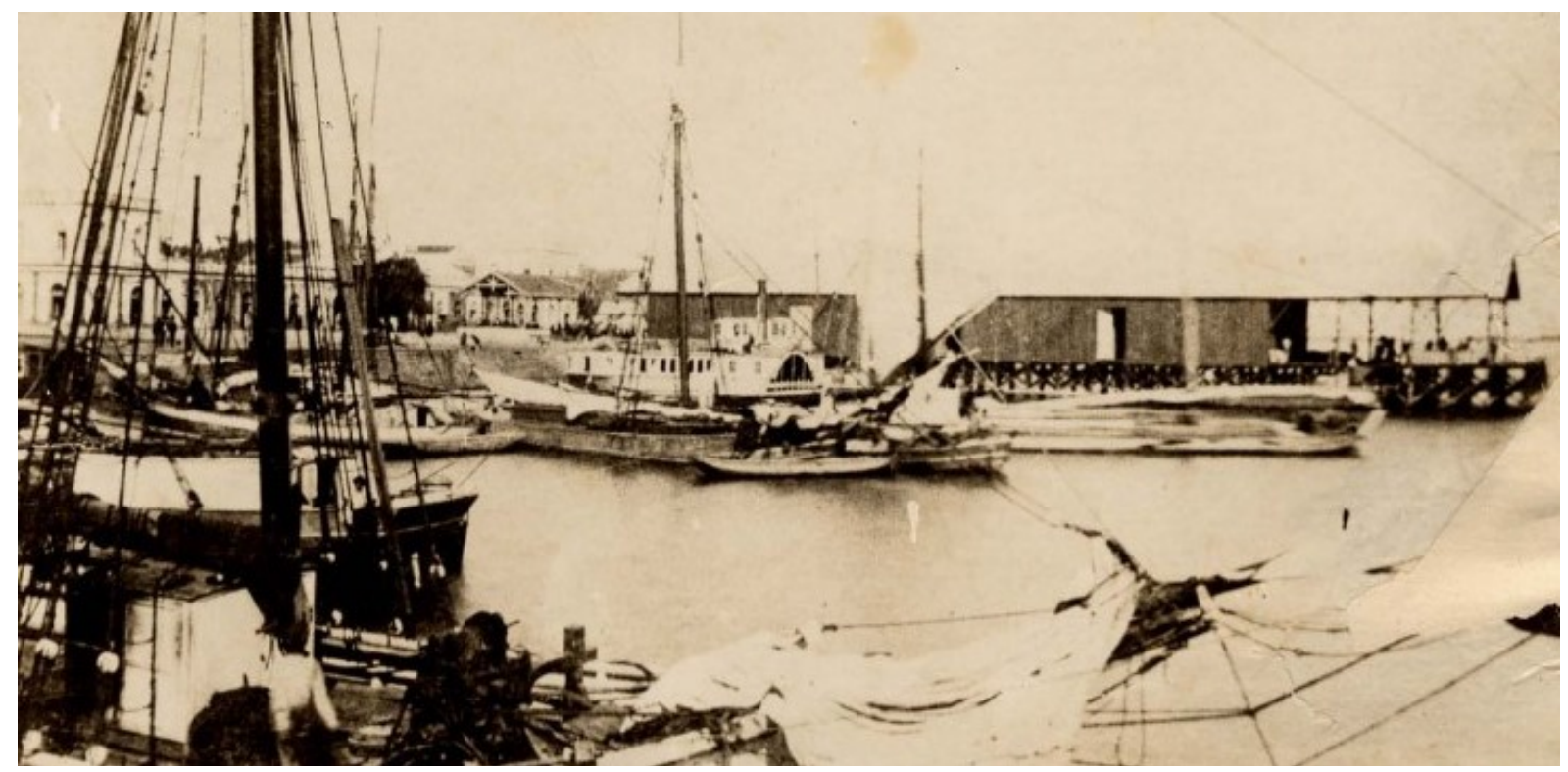

Figura 12. O cais antigo na última década do século XIX. Fonte: Acervo do Museu Joaquim José Felizardo/Fototeca Sioma Breitman.

Grande parte deste esforço parte da elite política de formação positivista que regia o Estado. Desde o início da República, o grupo liderado por Júlio de Castilhos assume o controle do Rio Grande do Sul e implanta um regime de caráter positivista, baseado no lema republicano de "ordem e progresso". O partido perdurou no poder por mais de trinta anos, deixando marcas profundas na política estadual.

O Partido Republicano Rio-grandense (PRR), procurou oferecer novas soluções para antigos problemas, valorizando a base e buscando a adesão de classes médias urbanas que até então estavam longe do jogo político do Estado. A doutrina positivista dominou as ações do governo. As estratégias de atuação estavam direcionadas a modernização da cidade, através da tríade 
embelezamento, saneamento e novos equipamentos. Em matéria de urbanismo, isto se traduzia em um Plano de Melhoramentos.

0 porto representava uma oportunidade única neste contexto. Tanto para o governo quanto para a elite local, o novo equipamento iria desenvolver a economia gaúcha, inserindo o Estado na rota do comércio internacional.

\subsection{Plano de Melhoramentos}

A expressão 'melhoramentos urbanos', presente em estudos de inúmeras cidades brasileiras ao final do século XIX e início do século XX, designava embelezamento, abertura de vias, praças e obras de saneamento.

O estímulo por um novo urbanismo se reflete em todo país, e nasce da vontade de romper com a sociedade agrária tradicional. Partindo de um imaginário urbano ideal, os principais planos de todo Brasil apontam amiúde referências ao centro do país, principalmente no que se refere as reformas urbanas do Rio de Janeiro.

Desenvolvimento industrial tecnológico estava nas intenções destes planos, ainda que as condições reais se mostrassem limitadas. Em condição de Capital Federal, o Rio de Janeiro inaugurou as obras de remodelação urbana no país, visando transformar a cidade em um modelo de metrópole moderna e cosmopolita, digna de sua posição de sede dos poderes político e econômico. As obras do porto configuravam elemento chave dentro do processo de modernização: pequenos embarcadouros e trapiches foram apagados deram lugar a um cais retilíneo, com 3500 metros de extensão e novas estruturas.

No contexto porto-alegrense não será diferente. O primeiro plano urbanístico de Porto Alegre, titulado Plano Geral dos Melhoramentos e designado ao engenheiro-arquiteto João Moreira Maciel, segue o lema 'melhorar, conservando', e apresenta uma proposta baseada na abertura ou alargamento de vias, na consolidação urbana do aterro em execução na área do Cais do Porto, no saneamento e abertura do centro histórico e das margens do Guaíba e Riacho, e na implantação de novos espaços verdes públicos. A intenção era clara: redesenhar a imagem de Porto alegre.

Uma das medidas essenciais na proposta de Maciel era a abertura da Avenida Borges de Medeiros, via esta que teria papel articulador entre as áreas norte e sul da capital e o centro histórico. Tal articulação criaria, conforme a proposta do plano, um ponto focal: o largo do Mercado Público, possibilitando assim uma real conexão do centro com o Porto e, mais além, com o Lago Guaíba. 0 projeto do porto foi incorporado ao plano, com o cais retilíneo e uma série de avenidas dispostas na área que seria acrescida.

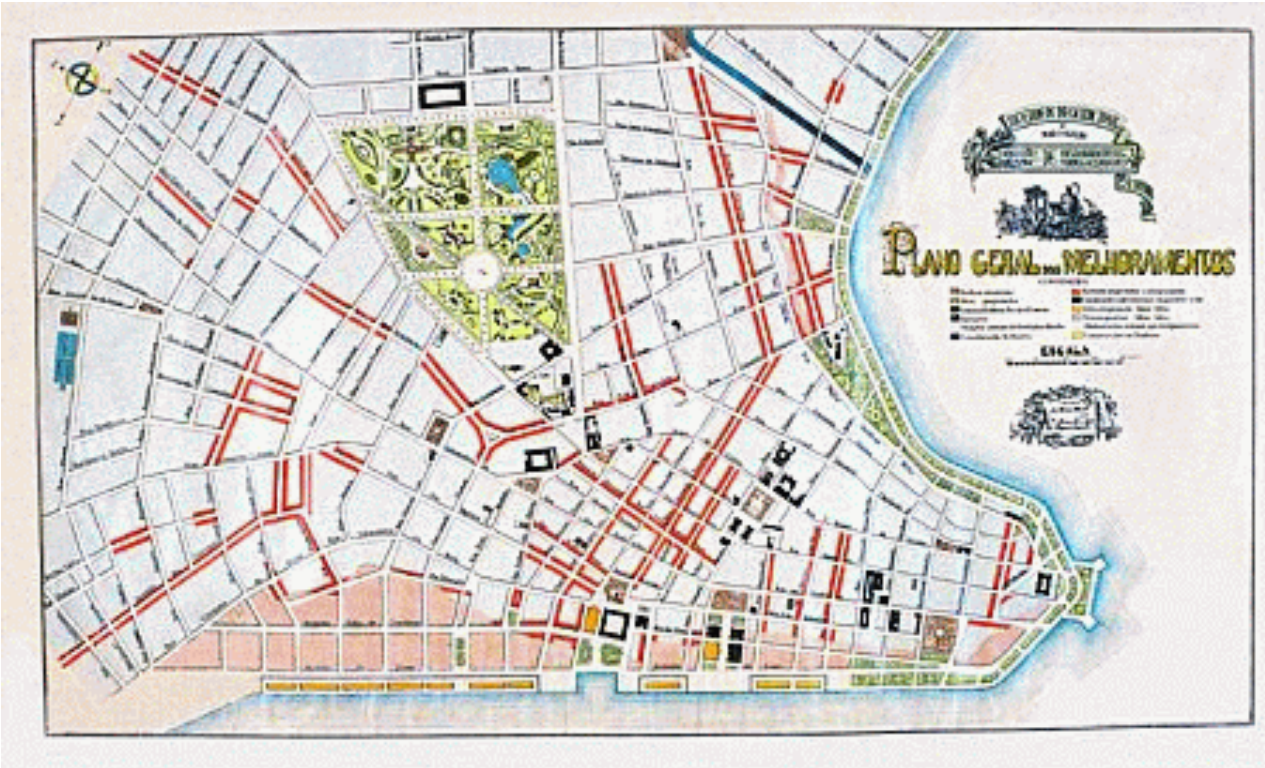

Figura 13. Plano Geral dos Melhoramentos, João Moreira Maciel, 1914.

Fonte documento original: Arquivo Histórico de Porto Alegre. 
O Plano de Maciel não foi um documento isolado, mas fruto do trabalho integrado. Este tratou-se de um documento chave por estar inserido no contexto de discussões sobre o urbanismo da capital, e sua execução tratou de se adequar aos desejos do governo republicano, sob a máxima de melhorar, conservando - criando assim os espaços necessários para abrigar uma nova Porto Alegre.

\subsection{A sala de visitas do Estado}

"Quem chega a Porto Alegre por água, mal deixa o vapor já se encontra em pleno coração da cidade (...)". Erico Verissimo, em apresentação do livro 'Lembrança de Porto Alegre' (1954), ilustra com poesia o contexto da praça mais imponente da capital, objeto de reformas e que rendeu outros versos de quem passou por ali.

Titulada como a sala de visitas do Estado, Porto Alegre sentiu-se no dever de redecorar seu espaço. A Praça da Alfandega, presente no contexto urbano desde as origens da cidade, foi nomeada e assim reconfigurada como porta de entrada de Porto Alegre em projeto vinculado à construção do novo porto para a capital do Estado.

Com a designação de 'Cais da Capital', o relatório de 1909 cita o trecho do projeto do cais em frente à Praça Senador Florêncio (atual Praça da Alfândega), onde se desejava construir uma nova área, própria para receber os visitantes de elevada posição social. Assim, o conjunto do porto e da Praça da Alfândega viria a ser o 'hall de entrada' de Porto Alegre. 0 termo incluso presente em discursos de representantes da cidade, estava diretamente relacionado à filosofia positivista da época. $\mathrm{A}$ capital do estado do Rio Grande do Sul deveria passar imagem de ordem e progresso, slogan do Partido Republicano Rio-grandense.

0 prestígio que as classes dirigentes buscavam se mostra claro na reformulação da Praça da Alfândega e a grande avenida projetada, que faria a conexão entre a área portuária e o Palácio do Piratini, através de uma avenida monumental. No ponto do portão do cais, área que ainda existia somente em projeto, estava prevista uma escadaria de acesso ao rio, e que funcionaria como porta de entrada da cidade. 0 projeto é assinado por Attilio Alberto Trebbi, primeiro desenhista da Secretaria de Obras Públicas do Estado.

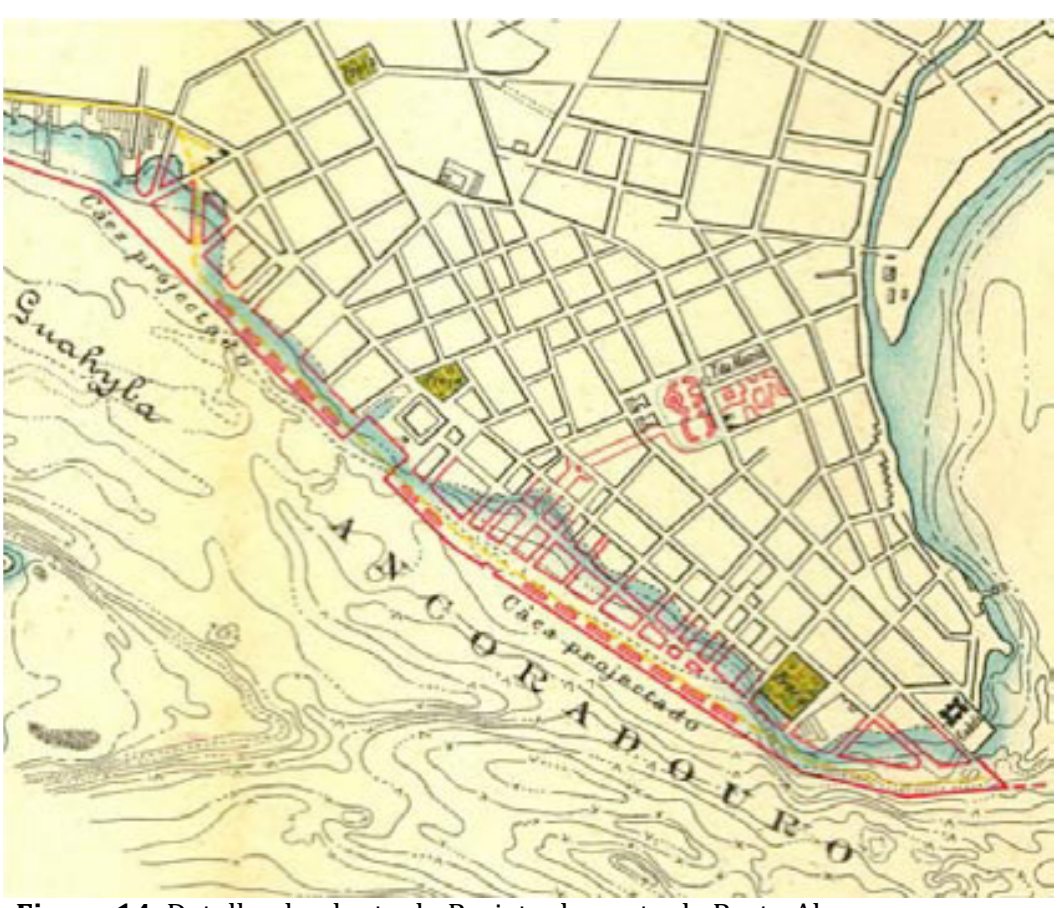

Figura 14. Detalhe da planta do Projeto do porto de Porto Alegre. Fonte: Secretaria das Obras Públicas. Diretoria da Viação.

[...] a avenida em questão além de vir a concorrer para o embelezamento da capital, estabelece uma comunicação muito conveniente entre a parte baixa e a parte alta da cidade, e a sua importância será ainda maior [...] si o Governo do Estado conseguir [...] construir o trecho de cães com escadarias, para o movimento de passageiros no porto (Godoy, 1909, p. XII)

De fato o projeto do novo porto de Porto Alegre fomentou a transformação urbana e arquitetônica de todo o entorno. No caso da Praça da Alfândega, além do tratamento inspirado nos jardins franceses, outras edificações foram erguidas sobre o terreno conquistado. Dois prédios gêmeos, projetados por Theo Wiederspahn, abrigavam a Receita Fiscal (atual Museu de Artes do Rio Grande do Sul) e os Correios e Telégrafos (atual memorial do Rio Grande do Sul), e emolduravam o eixo da nova avenida. Mais à frente, outros dois prédios gêmeos seriam construídos: o prédio de Mesa de 
Rendas (Secretaria da Fazenda) e o de Obras Públicas, obras de Afonso Hebert. A imagem arquitetônica, de linguagem historicista eclética, remarcou com imponência a monumentalidade que se buscava para a porta da cidade.
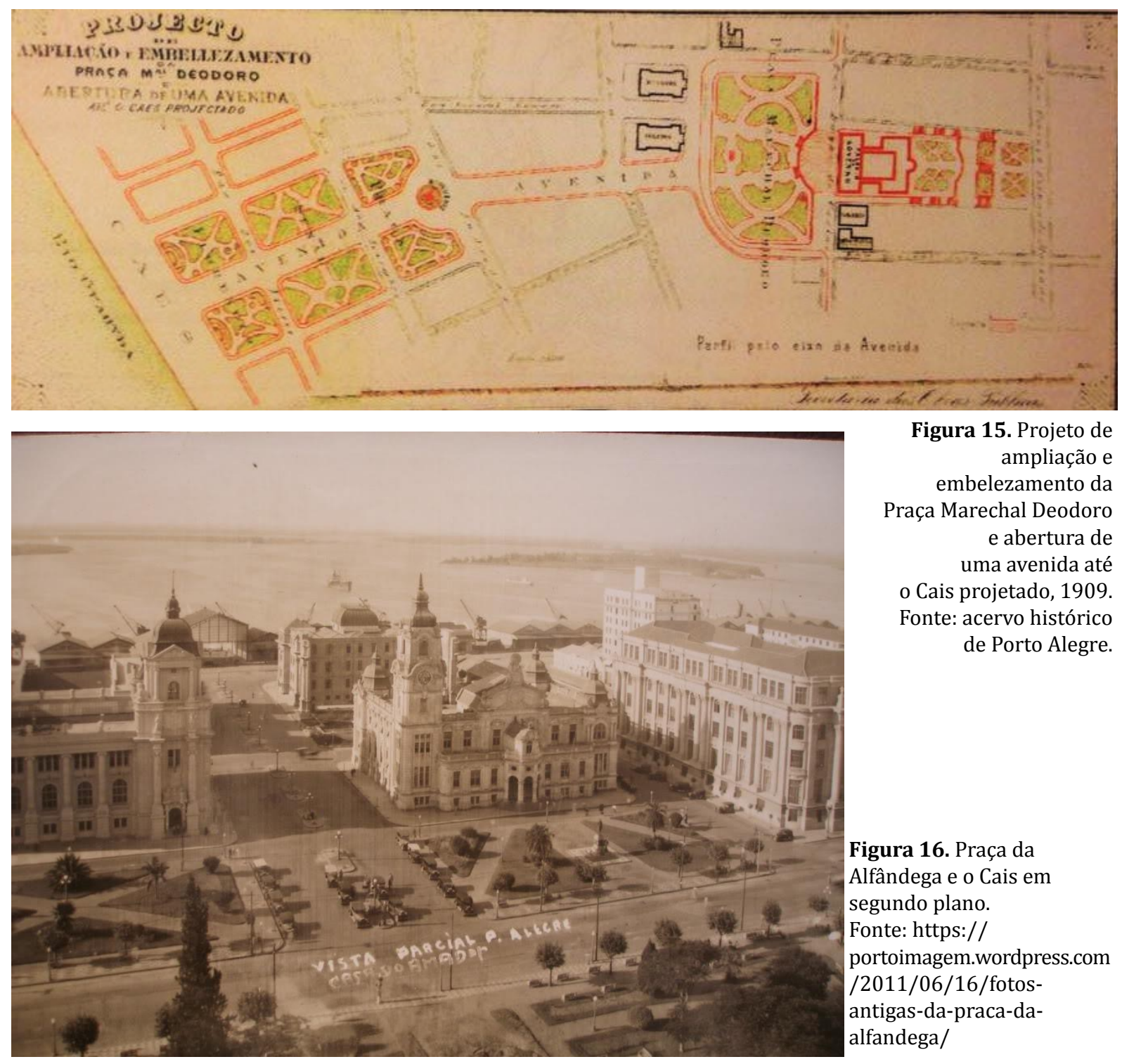

Figura 15. Projeto de ampliação e

embelezamento da Praça Marechal Deodoro e abertura de uma avenida até o Cais projetado, 1909. Fonte: acervo histórico de Porto Alegre.

Figura 16. Praça da Alfândega e o Cais em segundo plano. Fonte: https:// portoimagem.wordpress.com /2011/06/16/fotosantigas-da-praca-daalfandega/

Nos anos seguintes, hotéis e clubes animaram o entorno da praça. A antiga Praça da Quitanda trocou as frutas, o charque e as hortaliças por cafés e pratos requintados dos restaurantes. 0 que não mudou foi o movimento, a dança quase rotineira dos bondes e transeuntes. Parece que a praça já nasceu coração, viva e pulsante.

\subsection{Porto Alegre, porto de mar}

O simbolismo de um projeto para um novo porto, além das outras operações urbanas que acompanharam o ideário de embelezamento da capital, transpassa temas técnicos e econômicos. O imaginário urbano envolvido nesta epopeia teve papel substancial na construção do porto; foi motor na concretização de um sonho antigo: se afirmar como capital do estado e acertar o passo com a história.

As iniciativas para a reconfiguração da costa foram encabeçadas pelos engenheiros Cândido José de Godoy e João Luiz de Faria Santos. Conhecido como "Porto Alegre porto de mar", o plano proposto pelos engenheiros tinha como objetivo maior franquear Porto Alegre à navegação transoceânica, através da construção de um porto moderno e equipado, além de obras na Lagoa 
dos Patos e do Guaíba. Para a proposta se concretizar, seria necessário o aprofundamento dos canais de navegação e a desobstrução da barra de Rio Grande. Os textos do relatório reportam a relevância do projeto:

Me parece incontestável a utilidade deste empreendimento, de fácil realização e ao alcance dos recursos materiais do Estado. Ele assegurará a supremacia comercial de Porto Alegre, cuja posição topográfica a destina a ser um vasto entreposto de produção de uma grande parte de nosso Estado. Com efeito, situado na confluência dos rios Jacuhy, Cahy, Sinos e Gravatahy, todos navegáveis, [...] Porto Alegre tem e continuará a ter por intermédio deles transporte barato para a região por ele banhada. Esta é extensa e regularmente cultivada. As pequenas embarcações que navegam nestes rios interiores, não podendo sem risco atravessar a Lagoa dos Patos nem competir em frete com os grandes navios que os canais do Guaíba e da lagoa admitem, serão sempre obrigados a descarregar nesta capital (Faria Santos, 1904, p.159).

Segundo os engenheiros, a diminuição dos fretes marítimo e fluvial por si só fundamentava a justificação da audaz proposta. João José Pereira Parobé, então secretário de obras do Estado, aprovou o projeto e o repassou ao Presidente do Estado Borges de Medeiros, defendendo o valor deste para que Porto Alegre pudesse competir com o mercado externo. Em 16 de maio de 1904, o projeto foi motivo de elogios por estar em sintonia com os ideais do PRR.

Os autores do projeto estudaram diversos exemplos de modernização de portos e vias fluviais no continente europeu, buscando referências e diretrizes para o caso de Porto Alegre. Faria Santos defende, por exemplo, o sucesso de projetos como o "Paris Porto de Mar", do engenheiro Bouquet d e la Grye, na tentativa de demostrar o enorme valor da navegação de alto bordo e a influência determinante no progresso comercial.

Dentro deste contexto, os estudos de Francisco de Paula Bicalho, engenheiro e diretor técnico das obras do Porto do Rio de Janeiro, também lança diretrizes á capital gaúcha. Titulado "Plano para a realização do melhoramento dos portos da República", o estudo também analisa inúmeros portos europeus e norte-americanos. No entanto, Bicalho inova ao lançar diretrizes para a construção, modernização e administração de portos nacionais, ajustadas com a política nacional de desenvolvimento.

No entanto o enfoque de Bicalho era traçar ideais de administração dos novos portos do Brasil. Este defendia que as obras de melhoramentos dos portos não deveriam partir de capital privado, pois estes exigiam altas taxas para cobrir as despesas da construção. Como decorrência, o Estado deveria arcar com as despesas de tais empreendimentos, "como meio de animar o comércio e desenvolver as indústrias" (Bicalho, 1908, p.257). Ao sabor positivista, as diretrizes do governo federal correspondiam com as ideias expostas pelos engenheiros gaúchos.

A excepcional situação geográfica de Porto Alegre demostrava sua vocação: a cidade tinha todas as condições para abrigar uma área portuária promissora. No entanto, obras de grande escalão e de vital importância para o projeto estavam em primeiro plano: a linha de navegação da região deveria ser aprofundada até atingir o calado de cinco metros.

\subsection{Epílogo}

Guilherme Ahrons, então diretor de obras municipais, foi autor da primeira proposta para o cais da capital. Apresentado durante a administração do intendente Alfredo Augusto de Azevedo (1892-1895), o projeto se preocupava basicamente em sanear a área costeira da cidade, servindo o cais para a passagem do emissário da rede de esgotos da cidade. A área construída era de pequenas dimensões comparada ás propostas posteriores, mas logrou por lançar a luz uma nova imagem para a área.

No entanto, em 1896, o governo estadual apanha para si o cargo de tal tarefa de reconfigurar a costa portuária. Faria Santos inicia o projeto para o porto no ano seguinte, e os apresenta em outro de 1899, após levantamentos e estudos de toda região. 0 Cais proposto se estendia da antiga Ponta 
de Paris (Rua Garibaldi) até a Volta da Cadeia, na extremidade da península, totalizando quase três mil metros de extensão. Previa somente duas docas, uma em frente ao Mercado Público e outra na Praça da Harmonia. A proposta, por ainda não se cogitar a navegação marítima, sugeria o calado máximo de três metros, mas Faria Santos já destacava a importância de abrir a barra de Rio Grande.

O governo resolver adiar a execução do projeto, por força de concentrar seus esforços na dragagem dos canais de navegação. Após a apresentação dos estudos do "Porto Alegre porto de mar", em 1904, o projeto para o novo cais era dividido em três secções de profundidade: 2, 4 e 6 metros, respectivamente. 0 muro do cais avança e ganha mais sessenta metros em relação ao projeto anterior, afim de dar mais espaço aos armazéns.

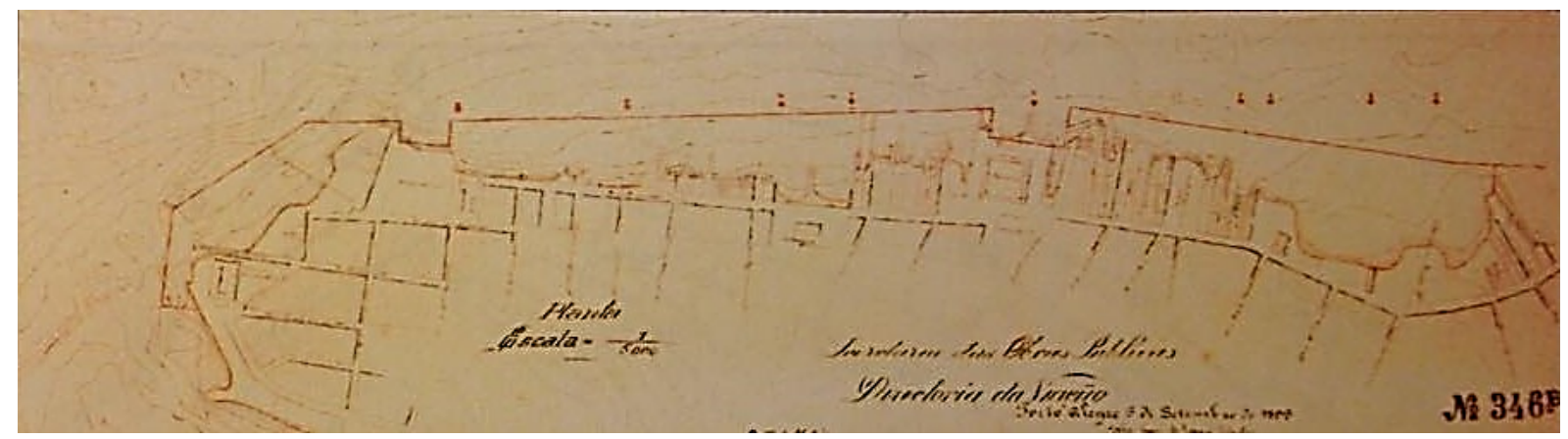

Figura 17. Traçado do Cais sobre o antigo litoral. Diretoria da Viação,1899. Fonte: Mapoteca DEPRC.

Segundo Relatório de Obras, em 1910 se encontrava organizado o anteprojeto do porto da capital, com 14 armazéns e 3.200 metros de extensão. O Cais possuiria uma rua de 60 metros de largura e estaria separada do porto por um gradil de ferro. Na imagem do projeto tornar-se evidente a integração do projeto do porto com a remodelação de outras partes da área central de Porto Alegre. 0 edital para a construção do primeiro trecho do cais, algo em trono de 140 metros em frente à Praça da Alfândega, foi lançado em fevereiro de 1911, e a proposta vencedora foi de Rudolf Ahrons. Assim, o primeiro trecho do porto, de 146 metros, foi entregue em 7 de outubro de 1913.

Após esta primeira etapa, a Secretaria de Obras lançou o segundo edital, convocando os concorrentes afim de seguir a construção do cais e as obras de abertura dos canais de navegação. Três propostas entraram na disputa: a primeira da Societé Française d'Enterprises de Dragages el Travaux Publics, a do engenheiro Rudolf Ahrons e uma última da empresa Gobrueder Goedhardt. A primeira proposta foi aceita, porém a companhia não conseguiu dar início às obras por carência de material e equipamentos.

Outro edital foi publicado no ano de 1916, este agora com enfoque na construção de um novo trecho de 600 metros, que se estenderia da Praça da Alfândega até a Rua Vigário José Ignácio. A proposta da empreiteira Álvaro Pereira e Cia foi aprovada, mas a história de atrasos e empecilhos para a construção se repetiu: haviam poucas condições técnicas para tal empreendimento.

Passadas para a superintendência da Comissão de Melhoramentos da Navegação Fluvial Lacustre, em 1919, as obras do porto somavam somente um total de 227 metros construídos. Estruturas metálicas provenientes da francesa Casa Daydé, foram providenciadas para a construção dos armazéns projetados. No início do ano de 1920, o Estado comemora mais um contrato assinado: a Companhia de Navegação Costeira estaria responsável pela construção do cais de seis metros de calado, trecho de reconfiguraria o caráter do porto.

Outra nova proposta, mais audaciosa, foi aprovada em abril de 1920: o porto redesenhado teria um total de 9.700 metros lineares de cais, 20 quilômetros de linhas férreas e 17 armazéns de estrutura metálica. Estes últimos teriam medidas de 96 por 20 metros, com 1920 metros quadrados de área útil, e provido de um moderno equipamento para a movimentação das mercadorias, além de dois guindastes elétricos de pórtico de 2,5 toneladas. 


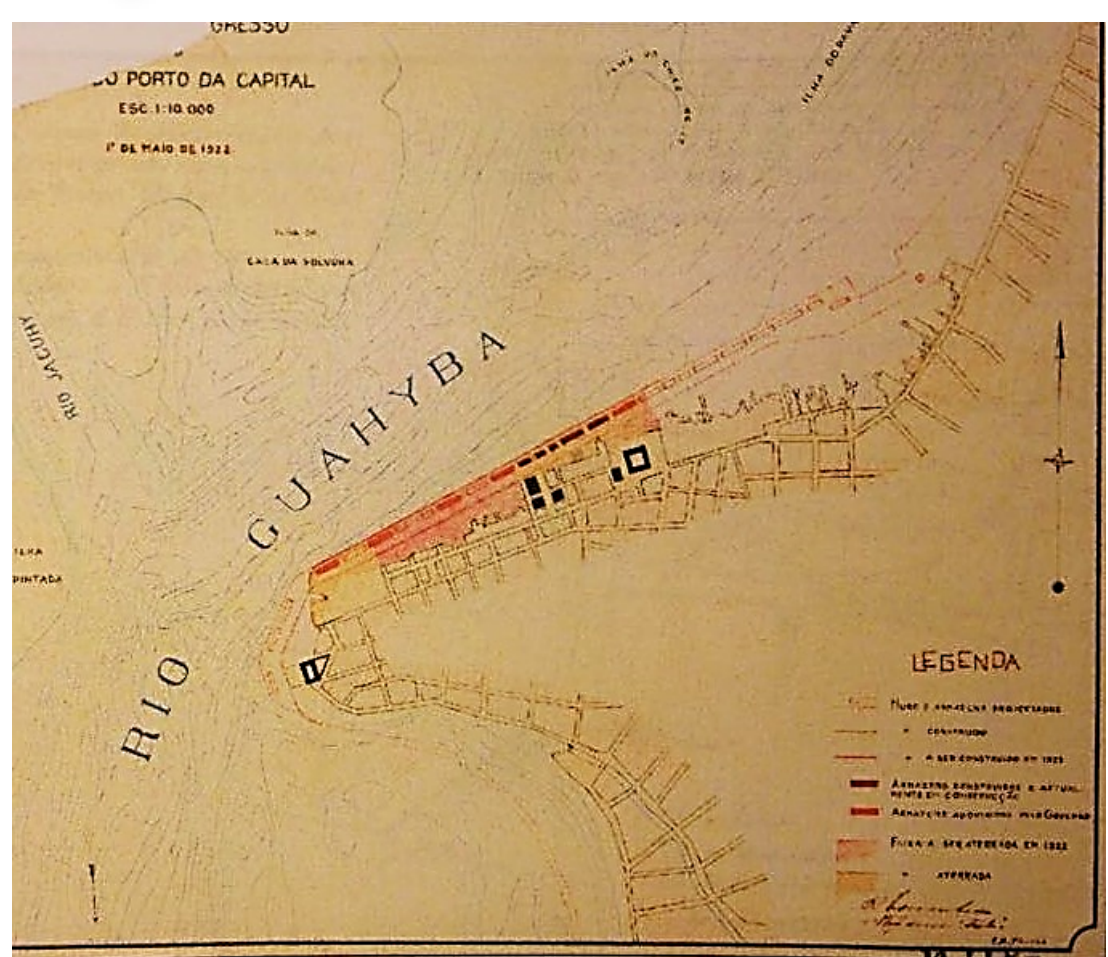

Figura 18.

Estágio de obras do porto, 1922. Fonte: Mapoteca DEPRC.

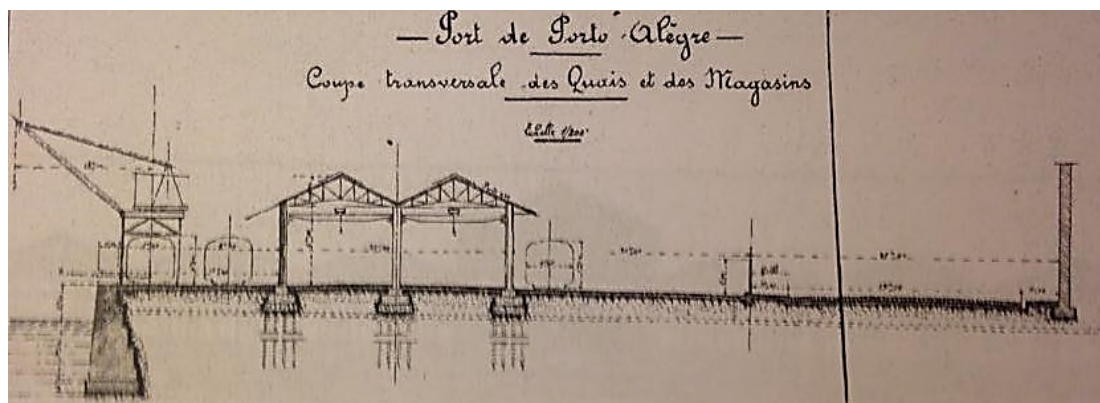

Figura 19.

Seção transversal do cais com os armazéns. Diretoria de Viação Fluvial. Fonte: DEPRC.

O ato oficial de inauguração deu-se em $1^{\text {o }}$ de agosto de 1921. O cais entregue à Secretaria da Fazenda contava com um armazém de estrutura metálica, um edifício em alvenaria que abrigava a administração do porto, e o armazém provisório B-1. Nas palavras de Faria Santos (1920, p.XXIX):

Esses armazéns são do tipo mais aperfeiçoado que se conhece, apresentando a vantagem da substituição das pontes rolantes por talhas patentes, muito cômodas para o deslocamento interno das mercadorias tanto em plano vertical como horizontal. As ossaturas metálicas dos armazéns, bem como as talhas e guindastes que as acompanham são de fabricação do estabelecimento Daudé, de Paris, o mesmo que forneceu os armazéns e guindastes do porto do Rio Grande (Faria Santos, 1920, p.XXIX).

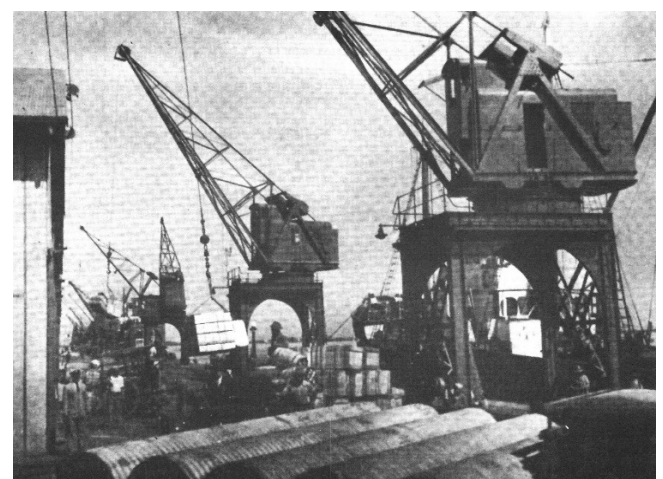

Figuras 20 e 21. 0 cais com os guindastes em funcionamento, 1930. Fonte: acervo DEPRC.

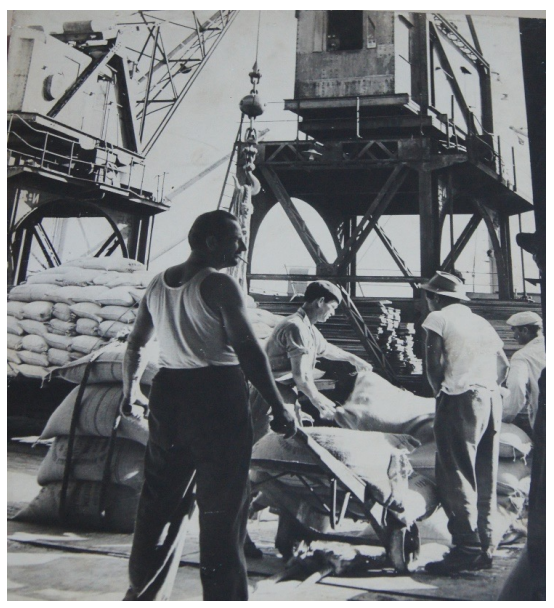


Em 1923, dois trechos construídos foram ligados, completando o cais de seis metros de calado, com uma extensão total de 896 metros de extensão. Nos anos que se sucederam, as obras para concretizar o porto seguiram dentro da normalidade, apesar dos movimentos revolucionários provocados por "inimigos das instituições Rio-grandenses." 0 fato de maior notoriedade foi quando, em 1930, a navegação de 17 pés alcança o porto da capital - ato de forte significado, após anos de sonhos, projetos e conquistas do governo gaúcho.

Até finais de 1929, o porto contava com um total de 2.181 metros de extensão, distribuídos nas quatro categorias de cais propostas: 6 metros, 5 metros, 4 metros e 2,5 metros de calado. Foram construídos um total de 13 armazéns, além do edifício de administração do porto e do pórtico central. Como um balanço de todos este esforço em modernizar o porto, o secretário de obras João Moreira revela os pontos positivos das atividades exercidas em prol de uma nova Porto Alegre:

O Rio Grande do Sul pode, no entanto, dizer com ufania que, dentro das suas possibilidades normais, tem procurado resolver tão complexos problemas, cautelosamente, e com mão segura; e para confirmar essa asserção, alí está o que tem sido feito na Viação Férrea, o que se tem melhorado na navegação entre Rio Grande e Porto Alegre, o que se tem dispendido na construção do importantíssimo cães desta capital, três serviços que, pelos vultuosos capitães neles envolvidos, bem dizem da visão larga e descortino amplo dos governantes do Rio Grande do Sul (Moreira, 1930).

\section{Conclusões}

O processo histórico é um processo de separação em coisas particulares, específicas. Cada nova totalização cria novos indivíduos e dá às velhas coisas um novo conteúdo. $O$ processo de totalização conduz da velha à nova totalidade e constitui a base do conhecimento de ambas (Santos, 1996, p.120)

A construção do porto de Porto Alegre foi um processo múltiplo: nasceu do desejo de adequar a cidade ao contexto internacional e transformou a antiga costa de retrato colonial em paisagem urbana moderna e ordenada. Os engenheiros do Estado buscaram referências em modelos que estavam sob os holofotes da época, e traçaram uma capital mais ajustada aos novos modelos econômicos do país. Por detrás destas respostas, havia uma sociedade com sede de progresso, mas com fome de preservar, com unhas e dentes, seu ideário singular.

A confiança quase cega do governo republicano, baseado nos princípios positivistas do partido, foi suporte básico neste processo. 0 desejo de transformação era tamanho que parecia correr pelas ruas e becos da capital como adolescente impaciente, o que contribuiu enormemente para a realização de um plano de modernização das estruturas porto-alegrenses.

0 projeto para um novo porto foi a chave a realização de um plano maior para a renovação global da cidade, baseado na tríade do urbanismo higienista: circular, sanear e embelezar. 0 foco estava principalmente no sistema de transportes do estado, o que dinamizaria a economia da região. Diante dos fatos, pode-se afirmar que a figura de João Luiz de Faria Santos, engenheiro que liderou a Diretoria de Viação e Viação Fluvial de Secretarias de Obras Públicas, se destacou por seu empenho em organizar e coordenar inúmeros projetos e estudos da obra, mas acima de tudo por acreditar fielmente no progresso da cidade de Porto Alegre.

Seja o trabalho braçal exercido pelos trabalhadores do porto, seja o esforço dos governantes em modernizar o símbolo original da cidade, ou ainda as inúmeras idas e vindas que o Cais testemunhou, a construção do porto escreveu sua história no território banhado pelas águas do Guaíba. A nova paisagem costeira, transformada em prol do desenvolvimento econômico e social da capital, é resultado de um trabalho esmerado. Em vista disto, os vestígios deste processo carregam especial simbologia por marcar no território uma história; narrar silenciosamente uma epopeia orgulhosamente gaúcha.

A história não deixa dúvidas que o povo gaúcho não tarda em esmerar sua terra. A cidade surgiu como uma ressonância do pampa, mas sui generis, Porto Alegre navega por seus próprios códigos, 
numa tentativa de moldar-se como a capital digna de um povo aclamado por suas conquistas. Ao visitante que Erico Verissimo apresentou à Porto Alegre, pode-se dizer que aqui encontra uma cidade que desde cedo procurou decorar sua casa, como ato de reverência ao cenário "de fabulosos crepúsculos" que lhe foi presenteada.

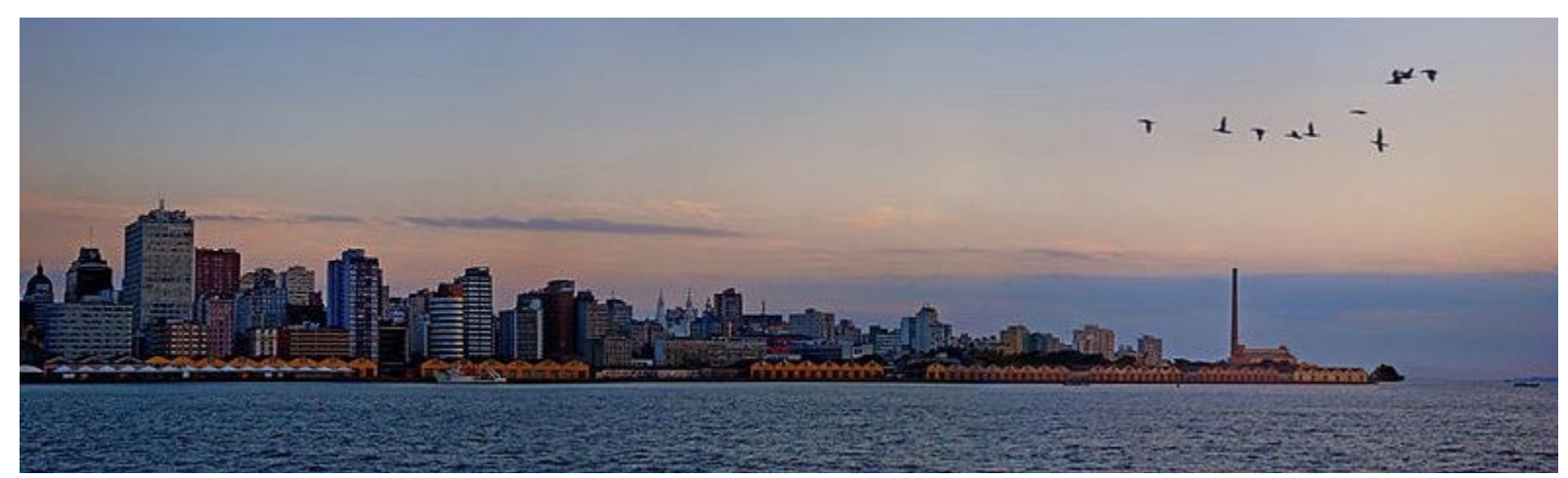

Figura 22. Vista do Cais de Porto Alegre. Fonte: https://pt.wikipedia.org/wiki/Porto_Alegre

\section{Referências}

Bicalho, F. P. (1908). Plano para a realização do melhoramento dos portos da República (R.D.V.F).

Coelho, C. (2013). Os Elementos Urbanos. Lisboa: Editora Argumentum.

Faria Santos, J. L. (1904). Relatório da Diretoria de Viação Fluvial (R.D.V.F.).

Franco, S. (1988). Porto Alegre, guia histórico. Porto Alegre: Editora UFRGS.

Frenchman, D., Sabaté, J., \& Schuster, J.M. (2004). Event Places. Barcelona: Universidad Politécnica de Cataluña, \& Massachusetts Institute of Technology.

Godoy, C. J. (1909). Relatório da Secretaria de Estado dos Negócios das Obras Públicas, apresentado a Carlos Barboza Gonçalves. Porto Alegre: Oficinas Gráficas da Livraria do Globo.

Inostroza, S. (2002). Huellas en la ciudad heredada: Complejidad y continuidad en la morfo-génesis del proyecto urbano contemporáneo. Tesis doctoral, Universidad Politécnica de Cataluña, Barcelona, España.

Lersch, I. (2015). A Praça da Alfândega como vestíbulo para a cidade: paradigmas e contradições de um espaço público. Anais do Congresso Internacional de Espaços Públicos, Porto Alegre, RS, Brasil, 1.

Menegat, R. (2006). Atlas Ambiental de Porto Alegre. Porto Alegre: Editora UFRGS.

Moreira, J. F. (1930). Relatório da Secretaria de Estado dos Negócios das Obras Públicas, apresentado a Getúlio Vargas (volume 1). Porto Alegre: Oficinas Gráficas d'A Federação.

Peixoto, N. (2003). Paisagens Urbanas. São Paulo: Senac.

Saint-Hilaire, A. (2002). Viagem ao Rio Grande do Sul. Martins Livreiro: Porto Alegre.

Santos, M. (2014). A natureza do espaço. São Paulo: Editora USP.

Sauer, C. (1925). The morphology of landscape. In J. Leighly (ed.). Land and life: a selection from the writings of Carl Ortwin Sauer. Berkeley: University of California Press.

Verissimo, E., \& Klettner, E. (1954). Lembrança de Porto Alegre. Porto Alegre: Editora Globo.

Verissimo, E. (2002). O Continente. São Paulo: Editora Geográfica. 